\section{SARS-CoV-2 (COVID-19) - Replicação da Informação Genética}

A pandemia COVID-19 é causada pelo coronavírus SARS-CoV-2. Este vírus, para se multiplicar, tem de replicar o seu material genético precisando, para isso, das células de um hospedeiro. 0 processo de replicação do genoma e transcrição dos genes deste vírus é realizado por uma RNA polimerase dependente de RNA [(RdRp) - RNA-dependent RNA polymerase] do vírus. Esta enzima (polimerase) liga-se ao RNA do vírus e copia-o. Os fármacos que interrompam esse processo de replicação podem ser úteis no tratamento da COVID-19, dado que este complexo RdRp é o alvo para os fármacos antivirais análogos a nucleósidos. O conhecimento da estrutura da polimerase de SARS-CoV-2 durante o processo de replicação poderá fornecer informações importantes com vista à otimização de fármacos com esse modo de ação, nomeadamente o remdesivir que está atualmente em estudo. Este fármaco apresenta atividade antiviral contra coronavírus em culturas celulares e animais, inibe coronavírus RdRp e está em ensaios clínicos como um candidato a fármaco para o tratamento da doença COVID-19.

Investigadores do Instituto Max Planck de Química Biofísica, Göttingen, Alemanha, determinaram a estrutura da RdRp do SARS-CoV-2 na sua forma de replicação (foto) usando microscopia eletrónica criogénica (crio-EM). Esta técnica utiliza temperaturas muito baixas permitindo a determinação de estruturas biomoleculares em resolução quase atómica. Esta polimerase consiste de três proteínas virais (nsp12, nsp8 e nsp7). A equipa de investigação expressou estas proteínas em células de insetos ou na bactéria Escherichia coli, purificou-as e reconstituiu a polimerase das proteínas purificadas. Depois, adicionou o RNA modelo para formar um complexo RdRp-RNA e realizou medições pela técnica crio-EM.

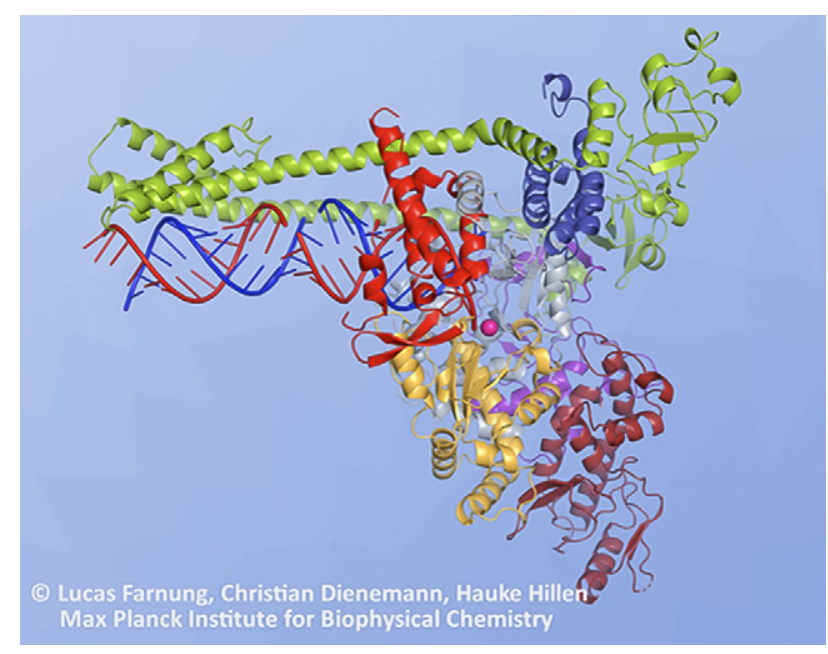

O RNA modelo e o RNA copiado formam um "dúplex" (representado a azul e vermelho no lado esquerdo da figura), análogo à dupla hélice do DNA. A estrutura que este grupo de investigadores determinou contém mais de duas "voltas" desse RNA dúplex para além das proteínas enzimáticas. Extensões helicoidais longas na proteína nsp8 (na figura, a verde, acima do RNA) projetam-se ao longo do RNA dúplex. Segundo os investigadores, essas "extensões" de proteínas podem ajudar a enzima a copiar o genoma, relativamente longo, do SARS-CoV-2 num processo contínuo, evitando a dissociação do produto.

Esta equipa de investigadores acredita que os resultados obtidos podem permitir uma análise detalhada dos mecanismos de inibição usados por antivirais, como o remdesivir.

$>$

\section{Ana Paula Esteves}

aesteves@quimica.uminho.pt

\section{Fontes}

How SARS-CoV-2 Copies Its Genetic Information, https://www.chemistryviews. org/details/news/11238721/How_SARS-CoV-2_Copies_Its_Genetic_ Information.html (acedido em 05/06/2020)

H.S. Hillen, G. Kokic, L. Farnung, C. Dienemann, D. Tegunov, Patrick Cramer, bioRxiv (2020). DOI: 10.1101/2020.04.27.063180 